\title{
Letter from the Editor: So Long, and Thanks for All the Fish
}

Early on in my tenure as editor of Central European History $(C E H)$, I published a piece that compared the development of the journal during the years before and after the so-called Wende of 1989-1990. ${ }^{1}$ The focus was on thematic, temporal, and geographic coverage, with an eye to changes that had taken place since the fall of the Berlin Wall-a happy event that, by chance, more or less coincided with the rise of the "new cultural history" in the late 1980s. It is only fitting that, in my last issue, I take stock once again, this time of the journal's trajectory over the past five years. This will allow readers to judge for themselves whether it has continued to meet the goals that Douglas Unfug, CEH's first editor, set forth a half century ago, namely, to "maintain a balance between works of broad synthesis and of specialized research, among studies of all periods from the Middle Ages to the present, and among studies using traditional approaches to history and those employing recent or experimental methodological approaches."2

Since I took over the editorial reins in July 2014, with Julia Torrie intrepidly serving as associate editor responsible for book reviews, CEH has published 85 scholarly articles and review essays, more than 250 reviews and featured reviews, as well as dozens of contributions to almost a dozen special issues and discussion forums. The "recent and experimental" have long since become the "traditional," of course, and it should come as no surprise that the vast majority of articles that have appeared over the past half-decade fall into the categories of social history and especially the (no longer quite so) new cultural history. Approximately 20 percent have dealt with gender and sexuality, with topics ranging from homosexuality and masculinity to abortion, female journalism, queer culture, and the Afro-German experience after 1945. Other noticeable Schwerpunkte have been nationalism and identity; religion, festivals, and celebrations; architecture and monuments; photography and the representation of power; memory and the media; colonialism and diplomacy; Jews and refugees; German division and the Cold War; 1968 and the New Left; (mental) health and illness; crime, language, and the law. There have also been a handful of articles as well on $u$ r-traditional topics such as high-level politics, state-building, voting patterns, and economics. Falling evenly on either side of the 1945 caesura, almost two-thirds of the articles that have appeared since 2014 treated the period after World War I. Approximately one-fifth dealt with the Kaiserreich and the First World War. Almost a dozen focused on the Middle Ages, the early modern period, and the Vormärz period; a half dozen on Austria and the Habsburg Empire.

Much of this keeps with recent trends in the field. I had hoped to publish more articles on the period prior to the Kaiserreich, as well as on the German-speaking regions of Central Europe beyond Kleindeutschland. But a journal and its editor are ultimately dependent on manuscript submissions, and the most popular topics continue to be the Third Reich and

\footnotetext{
${ }^{1}$ Andrew I. Port, "Central European History since 1989: Historiographical Trends and Post-Wende Turns," Central European History (CEH) 48, no. 2 (2015): 238-48.

2 "From the Editors," CEH 1, no. 1 (1968): 3.
} 
the two postwar German states. ${ }^{3}$ Julia Torrie and I have tried to redress this continuing imbalance in a number of ways - for example, by commissioning review essays, such as Katherine Aaslestad's survey of the new literature that appeared to mark the bicentennial of the Congress of Vienna in 2015, as well as Alexandra Bettag's in-depth review of an exhibition about the Renaissance recently put on in Zurich. We also organized several discussion forums that paid tribute to recent, sweeping studies on earlier periods in, and geographically broader regions of, Central European history-Peter Wilson's Heart of Europe: A History of the Holy Roman Empire, and Pieter Judson's The Habsburg Empire: A New History-as well as to a classic one on the occasion of its fortieth anniversary: Mack Walker's German Home Towns.

Six forums have appeared altogether over the past five years, featuring participants based in North America, the United Kingdom, Germany, Australia, Italy, Switzerland, and the Netherlands. The other three were "The Vanishing Nineteenth Century in European History?" "In Memory of the 'Two Helmuts': The Lives, Legacies, and Historical Impact of Helmut Schmidt and Helmut Kohl," and "Holocaust Scholarship and Politics in the Public Sphere: Reexamining the Causes, Consequences, and Controversy of the Historikerstreit and the Goldhagen Debate." There have also been lengthy review essays on topics such as the origins of World War I, new approaches to the study of the Weimar Republic, the relationship between the Nazis and the Islamic world, as well as the course of the Euromissile crisis of the late 1970s. Last but not least, four special issues have appeared in CEH since 2014: "Photography and Twentieth-century German History," "Masculinity and the Third Reich," "New Narratives for the Federal Republic," and a special issue commemorating the journal's fiftieth anniversary in March 2018. ${ }^{4}$ The anniversary issue was comprised of three main sections- "Recollections and Reminiscences," "Reflections, Reckonings, and Revelations," "Reveries and Reverberations"- and included more than two dozen essays by scholars who provided overviews of the history of the journal, the historiography of Central European history more generally, and the ways in which the journal has influenced the trajectory of the field over the past half century.

The commemorative issue, which featured a full-color frontispiece reproducing all eight covers of CEH since 1968 (there are now nine), was a high point. But there have also been lows. ${ }^{5}$ As editor, I have had the unenviable task of soliciting a dozen memorials for recently deceased colleagues - prompting one appreciative reader to write that the journal has now created, "through its memorials, a kind of archaeology about the writing of German history." Those scholars - all men, incidentally, and almost all born during the Weimar Republic-were Jonathan Osmond (1953-2014), Hans-Ulrich Wehler (1931-2014), Peter Gay (1923-2015), Hans Mommsen (1930-2015), Gerhard A. Ritter (1929-2015), Carl Schorske (1915-2015), Allan Mitchell (1933-2016), Ernst Nolte (1923-2016), Fritz Stern (1926-2016), Georg Iggers (1926-2017), Eberhard Jäckel (1929-2017), and

\footnotetext{
${ }^{3}$ Since the summer of 2014, CEH only received thirty manuscripts on the period prior to 1870 , and fewer than two dozen on the German-speaking parts of the Habsburg Empire and Switzerland.

${ }^{4}$ Another special issue has been accepted for publication and should appear imminently: "Burdens and Beginnings: Rebuilding East and West Germany after Nazism."

${ }^{5}$ For further discussion of the lows - including the challenges of academic publishing, and the socially challenged of our profession-see pp. 2-15 of Andrew I. Port, "Annual Report of the Editor of Central European History," Jan. 6, 2018 (http://www.centraleuropeanhistory.org/sites/default/files/2017_ceh_annual_report_aha.pdf).
} 
Douglas Unfug (1929-2017). ${ }^{6}$ CEH mourns the loss of these scholars, who shaped the profession and the study of Central Europe in countless ways.

At the same time, there is much for the journal to celebrate when looking back over the past five years-beginning with a number of innovations, including the now regular "Letter from the Editor," which provides an overview of the main themes, arguments, and scholarly significance of the articles in that issue. Yet, the most conspicuous innovation has arguably been the journal's larger format and arresting new covers, a colorful series of atmospheric cityscapes by the Berlin-based artist Edward Gordon, who kindly allowed us to use a different painting for each volume. ${ }^{7}$ Other innovations include color illustrations in the print copies of the journal - such as the striking one on page 197 of this issue: an image of a painted glass window showing the Virgin Mary as the apocalyptic Woman Clothed with the Sun-as well as the addition of abstracts in English and in German. My hope was that the latter would help the journal garner greater attention from German-speaking scholars and lay audiences, and this has apparently paid off, especially in terms of greater media coverage in Germany. For example, an abridged version of Benjamin Carter Hett's “"This Story Is About Something Fundamental': Nazi Criminals, History, Memory, and the Reichstag Fire," appeared in translation as a five-page special section of Die Welt am Sonntag in May 2015; and Anna von der Goltz's "Other '68ers in West Berlin: Christian Democratic Students and the Cold War City" was the subject of an article in the Frankfurter Allgemeine Zeitung in May 2017. ${ }^{8}$

For all this innovation, the editorial focus has been first and foremost on the quality of the articles, reviews, forums, memorials, and essays - in terms of content and clarity of style. This, too, has apparently paid off. CEH's so-called Impact Factor, which is based on the frequency with which its most recent articles have been cited, jumped to 0.485 in 2017 . This was its highest ever, placing it thirty-third on a select list of eighty-nine historical journals that receive an impact factor. CEH's reputation as the flagship journal in the field received additional confirmation when two recently published articles won major awards. In 2018, Marcus Colla's "Prussian Palimpsests: Architecture and Urban Spaces in East Germany, 1945-1961" received the prestigious Alexander Prize of the Royal Historical Society, which is awarded annually in the United Kingdom for "an essay or article based on original historical research, by a doctoral candidate or those recently awarded their doctorate, published in a journal or an edited collection of essays." The prize was established in 1897, and this was the first time that an article published in a non-British journal has won the award. James Retallack's “Mapping the Red Threat: The Politics of Exclusion in Leipzig before 1914" received an important honor as well: the biennial Hans Rosenberg Article Prize of the Central European History Society for 2015-2016, which "recognizes the best English-language article or essay on Central European history written by a permanent resident of North America."

Perhaps a small thing when compared to such illustrious accolades, but $C E H$ has achieved something else over the past five years, and it is an accomplishment about which I, too, am

\footnotetext{
${ }^{6}$ Memorials are also planned, alas, for Alf Lüdtke (1943-2019) and Axel Schildt (1951-2019).

${ }^{7}$ See Gordon's artwork at https://gordon.de.

${ }^{8}$ Benjamin Carter Hett, "Das Rätsel um den Reichstagsbrand," Die Welt am Sonntag, May 24, 2015; Martin Otto, "Die Brudermannschaft der Freien Universität meldet sich zurück," Frankfurter Allgemeine Zeitung, May 17, 2017.
} 
proud: almost every issue has appeared on time in the scheduled month of publication. ${ }^{9}$ Those familiar with the journal's past history will know that that is no mean feat. But it has come at considerable cost, not least to my family. And that is why it is only proper that I conclude my final Letter in my final issue as editor of $C E H$ by thanking my wife, Sylvia Taschka, and our two daughters, Hannah and Rebekka. ${ }^{10}$ They alone know what the past five years have cost us in terms of time, energy, and nerves. Still, I hope that they have felt at least a tiny bit of the great joy that I have felt every time a new issue arrived on our doorstep.

ANDREW I. PORT EDITOR

\footnotetext{
${ }^{9} \mathrm{I}$ am also glad to note, given concerns about the continuing underrepresentation of women in the field, that 40 percent of all the research articles and review essays that have appeared during my time as editor were written by women. In addition, $\mathrm{CEH}$ has recently published two important pieces that tackle the issue of gender disparities in the profession: Karen Hagemann and Donna Harsch, "Gendering Central European History: Changing Representations of Women and Gender in Comparison, 1968-2017," CEH 51, no. 1 (2018): 114-27; Christina von Hodenberg, "Writing Women's Agency into the History of the Federal Republic: '1968,' Historians, and Gender,” CEH 52, no. 1 (2019): 87-106 (esp. 88-91). For a discussion about gender representation in $C E H$, also see pp. 4-8 of Andrew I. Port, "Annual Report of the Editor of Central European History,” Jan. 5, 2019 (http://centraleuropeanhistory.org/sites/default/files/annual_report_of_the_editor_for_2018.pdf).

${ }^{10}$ Sylvia has also done a superb job of translating all the abstracts into German since the introduction of that practice in March 2015.
} 